\title{
The Rök Runestone and the End of the World
}

\author{
Per Holmberg (University of Gothenburg), Bo Gräslund (Uppsala \\ University), Olof Sundqvist (Stockholm University), and Henrik Williams \\ (Uppsala University)
}

\begin{abstract}
The Rök runestone from central middle Sweden, dated to around $800 \mathrm{CE}$, is famous, among other things, for a supposed reference to the emperor Theodoric the Great. This study proposes instead that the inscription deals with an anxiety triggered by a son's death and the fear of a new climate crisis similar to the catastrophic one after $536 \mathrm{CE}$. Combining perspectives and findings from semiotics, philology, archaeology, and history of religion, the study presents a completely new interpretation which follows a unified theme, showing how the monument can be understood in the socio-cultural and religious context of early Viking Age Scandinavia. The inscription consists, according to the proposed interpretation, of nine enigmatic questions. Five of the questions concern the sun, and four of them, it is argued, ask about issues related to the god Odin. A central finding is that there are relevant parallels to the inscription in early Scandinavian poetry, especially in the Eddic poem Vafprúðnismál.
\end{abstract}

Keywords: Rök, runestones, Viking Age, riddles, Eddic poetry, skaldic poetry, climate crisis

$\mathrm{T}$ he Rök runestone (Ög 136) is the most famous runic monument of the Viking Age. It was erected c. $800 \mathrm{CE}$ in a prosperous agricultural district in today's central middle Sweden by Varinn as a memorial to his son Vāmōðr. Except for one damaged line, its more than 700 runes and other characters are still clearly legible, and cover all five visible sides of a five-ton granite slab, over two and a half meters high above the ground. A century and a half of scholarly investigation has however failed to establish persuasively what the inscription means, or provide a con-

Holmberg, Per, Bo Gräslund, Olof Sundqvist, and Henrik Williams.

"The Rök Runestone and the End of the World."

Futhark: International fournal of Runic Studies 9-10 (2018-2019): 7-38.

DOI: $10.33063 /$ diva-401040 
vincing understanding of its function. This study argues that the inscription like almost all Viking Age runic memorials deals with the death and sometimes afterlife of a relative, a tragedy intensified by the anxiety connected with recent disasters and catastrophic events related to the climate crisis after $536 \mathrm{CE}$.

The Rök runestone was first documented in the seventeenth century when it was used as a building block in a medieval building by the Rök church. The first difficulty in understanding the inscription is presented by its use of different orthographical systems. The short-twig runes used on the front side, the first narrow side, and the main part of the back of the stone were correctly read by Sophus Bugge (1873-78; 1910), who also succeeded in decoding the substitution cipher on the back. The two lines with older futhark runes on the back, as well as the three lines with a numerical cipher, were given a relatively convincing reading by Otto von Friesen (1920). While there is general agreement on the identification of the runic characters and the decipherment of the cryptic passages (we follow the standard transliteration), no consensus has been reached on the reading order of the inscription. More than fifteen solutions have been proposed (cf. Lönnqvist 1999; we follow none of them). Also the dating has been re-examined in the scholarly debate, but the conclusion that the inscription is carved around $800 \mathrm{CE}$ seems to stand (cf. Barnes 2007 for arguments against a later dating).

The standard interpretation has been to identify a sequence of runes on the front side of the stone with the name Theodoric (first suggested by Guðbrandur Vigfússon in Vigfússon and York Powell 1879, 452), and to understand this as a reference to the Ostrogoth king Theodoric the Great, who ruled in Ravenna in 493-526 CE. A central challenge for most twentieth-century proposals has been to offer a coherent explanation of this reference. The other supposed actors in the inscription, such as IngivaldR, Sibbi, and Vilinn, have been assigned roles that match the adopted Theodoric frame.

The most influential proposal has been Elias Wessén's that Varinn wanted to show off his extensive knowledge of hero narratives (Wessén 1958, cf. already Brate 1918, 250, and later Lönnroth 1977, Widmark 1992, Harris 2010). Other interpretations have made stronger claims about the relationship between Varinn and Theodoric. It has been suggested that Varinn claimed kinship with Theodoric by alluding to his valor (Schück 1908, Grønvik 2003), that Varinn's son was in fact considered the reborn Theodoric (Bugge 1910, $37 \mathrm{f}$.), or that Varinn wanted to consecrate his son to Theodoric who was deified as Odin (Höfler 1952, e.g. 81 f., cf. Nielsen 
1969, 31). Other suggestions have been inspired by the ambivalent medieval reception of Theodoric the Great in the legends about Dietrich, and take the reference to be a warning example (Lindroth 1911, Pipping 1932). Some interpretations even take Theodoric to be an enemy figure, however referring to someone other than Theodoric the Great. It has been asserted that the name is that of a later Gothic king who would have fought a battle in the vicinity of Rök (Friesen 1920, 46-48), or a Frankish king and namesake who would have been an enemy of the early kin of Varinn (Malone 1934, Jacobsen 1961, 8-11).

A dividing line through the sprawl of different proposals has been whether the function of the inscription is understood as primarily narrative or ritual. Proponents of narrative interpretations argue that the inscription is a sequence of allusions to narratives, of which Theodoric is the main character of the first one (e.g. Schück 1908, Pipping 1932, Wessén 1958, Jacobsen 1961, Lönnroth 1977, Harris 2010) and struggle hard to find meaningful connections to the following supposed narratives and a motive for the monument. The ritual interpretations have been forced to speculate about how conceptions of Theodoric might have had a specific importance for the funeral of Vāmōðr (e.g. Brate 1918, Höfler 1952, Nielsen 1969). We will demonstrate that the function is both narrative and ritual.

In a more recent study Bo Ralph (2007) has argued that the Theodoric reading has led research into a dead end, and should be abandoned (cf. also Holmberg 2016). The present study is inspired by that line of reasoning.

The most important feature of our new approach is a consistent comparison with Old Norse texts dealing with events tied to Ragnarok (Ragna$r q k)$, the end of the world. A number of researchers before us have pointed to parallels in mainly Eddic poetry, but also in other Old Norse literature. We would however assert that this parallelism is far more pronounced than previously thought and that in fact the whole of the Rök inscription deals with an eschatological theme evidenced also in Eddic and skaldic poetry. We realize that positing such close ties to texts only attested many centuries after $800 \mathrm{CE}$ might sound too daring. The origins of Eddic poems are notoriously hard to pinpoint in time. Datings have ranged from before the Viking Age to as late as the Middle Ages (cf. Harris 2016, 39-42). The most recent discussion, as far as we know, of Eddic poetry dating (Thorvaldsen 2016) symptomatically comes to no definite result. ${ }^{1}$

${ }^{1}$ The eschatological tradition about Ragnarok is best preserved in the Eddic poems Vqluspá and Vafprúðnismál. Voluspá is usually dated to c. 1000, but recently it has been regarded as an early-tenth-century poem (see Hultgård 2017, 75, cf. Jónas Kristjánsson and Vésteinn 
Nevertheless, we maintain firstly that some mythological motifs were known already in the beginning of the Viking Age, also in eastern Scandinavia, secondly that it is not the poems themselves that we claim to have existed that early, but only the narrative contents in some (presumably mainly oral) form. Scholars do agree that not all poems are of the same age, and it should be borne in mind that their first origin and their written attestation might be centuries apart; in any case, Eddic poetry is an important source to heathen beliefs (cf. Meulengracht Sørensen 1991, $225 \mathrm{f}$.).

The earliest of the skalds, Bragi hinn gamli Boddason, was active in the first half of the ninth century and thus almost contemporary with the Rök carver. Bragi dealt with events in Norse mythology. In his Ragnarsdrápa there are allusions to the everlasting battle Hjaðningavíg, to the Sigurd cycle and to heathen deities, as well as to the wolf Fenrir (cf. Clunies Ross 2017a, 30-45), all elements also represented in Eddic poems. In the fragments of his poem about Pórr's fishing expedition we find the same basic narrative as in the Eddic poem Hymiskviða and Snorri Sturluson's Edda (cf. Clunies Ross 2017b, Faulkes 2005, 44 f.).

Eddic motifs in pictorial form are found on late Viking Age runestones, including scenes specifically representing Ragnarok (Jansson 1987, 14452). One of the motifs on the Gotlandic picture stones from the Late Merovingian Period and the Viking Age, which have been seen as true analogies to the Rök stone (Wessen, 1958, 71), can possibly support the belief that dead retainers were expected to be welcomed to Valhalla (Valholl) by the valkyries (valkyrjur, sing. valkyrja) who offered them mead from a horn at their arrival. On these stones we see a rider sitting on an eight-legged horse. He is welcomed by a lady who offers him a drinking horn. Already in the early twentieth century, Fredrik Nordin $(1903,150)$ interpreted this as a mythic scene, where one of Odin's warriors (einherjar) was invited to Valhalla by a valkyrie. This motif can, for instance, be seen on the eighth century Tjängvide 1 stone from Alskog parish, Gotland (Nylén 1988, 69 f.; critically considered by Hultgård 2017, 171-75). The fact that the horse on the stone has eight legs supports this interpretation, since Odin's horse Sleipnir had that shape in the Old Norse traditions. The motif on the stone may be related to the burials of aristocratic warriors and to the eschatological belief that they will take part in the final battle of Ragnarok.

Ólason 2014, 1: 131). Vafprúðnismál is usually conceived of as an early Eddic lay, perhaps from the early tenth century, but also this dating has been debated (see Jónas Kristjánsson and Vésteinn Ólason 2014, 1: 176 f., cf. Hultgård 2017, 122). Translations from Eddic poems are our own. 
There is also the question of how much people knew of ancient events around $800 \mathrm{CE}$. The perhaps oldest heroic poem of all, Hloðskviða ("The Battle of the Goths and the Huns") is set in the era of the Migration Age (roughly between the fourth and sixth centuries CE) but is preserved only in the medieval Hervarar saga. The ninth century skald Pjóðólfr ór Hvíni's Ynglingatal recounts episodes twenty-seven generations back, and Háleygjatal a century later had probably the same number originally (Sundqvist 2002, 46). On the Rök stone mention is made of an incident nine generations back. Considering that previous scholars take it for granted that this refers to Theoderic the Great from the early sixth century and that he was still remembered hundreds of years later, it should not be a problem if we posit the memory of an occasion contemporary with Theodoric.

The Rök inscription is too complex and offers too many interpretational possibilities to merely read word by word and from there arrive at the purpose of the text. Magnus Olsen $(1921,207)$ argued that it is risky to construct an overall view primarily based on the linguistic interpretation of separate sections and that one must rather externally elucidate the inscription as a whole (cf. also Widmark 1992, 29). In practice this means that it is necessary to have some idea of a unified understanding of this runestone's text even before trying to explain it, the testing of a hypothesis in other words.

\section{Analytical perspective of the study}

The Rök runestone belongs to a small set of Viking Age stone monuments carved before the runestone boom in the second half of the tenth century (Akerström 2019). Though these early monuments are dissimilar in terms of structure, function, and content, three abstract common denominators of their semiotics have guided our interpretation of the Rök runestone (cf. Holmberg 2016, 67-69). The establishment of these three principles is informed by the theory of social semiotics, and its understanding of linguistic meaning in three dimensions: textually as different ways of organizing text, ideationally as resources for construing the world, and interpersonally as potentials of interaction between the text and its readers (Halliday 1978).

First, the textual organization typically leads the reader stepwise towards the end of the inscription. This aligns with later Viking Age inscriptions (cf. Bianchi 2010, 73-84). The application of this principle to the Rök runestone inscription makes it clear that previous proposals for reading order have not succeeded in finding a way through the inscription without jumps between lines that are not spatially connected. 
Second, the ideational content of other early Viking Age inscriptions represents mainly local actions. Previous interpretations of the Rök runestone have, in spite of this pattern, tended to assume that references are being made to deeds performed far away from the stone. A main difference between the interpretation we have established and the standard one by Wessén, as well as other previously suggested alternatives, is that we do not recognize any of the same set of actors, whether Theodoric, Ingivalds, Sibbi or Vilinn (Wessén 1958, 15-17).

Third, the interpersonal demand on the reader to respond to the inscriptions of all Viking Age stone monuments is typically signaled linguistically by grammatical choices at clause level that express speech acts of statements or prayers, opening up the monument as a place for interaction. This contrasts with earlier runic monuments, where response alternatives are typically implicit. In the case of the Rök runestone it is evident that previous research has tended to downplay the dimension of interaction, and presupposed that the inscription substantially consists of statements, instead of noticing the constant shift between different speech acts.

In contrast to all previous interpretative attempts, we try to tie the contents of the Rök text quite closely to other early Scandinavian texts, primarily to two Eddic poems: the wisdom contest in Vafprúðnismál (Jónas Kristjánsson and Vésteinn Ólason 2014, 1: 356-66) and the apocalyptic vision of the seeress in Voluspá (1: 291-307), and to two skaldic poems in the Eddic style, the anonymous Eiríksmál (Fulk 2012a) and Hákonarmál by Eyvindr skáldaspillir Finnsson (Fulk 2012b), which deal with the death of King Eiríkr Bloodaxe and King Hákon the Good respectively. We do not claim that the extant poems were known in $800 \mathrm{CE}$ but that the mythology and ideology which form their basis did. Earlier efforts to find intertextual parallels, such as Olsen's important attempt to show how the Rök runestone resembles the structure of questions (twelve of them even numbered, resembling the numbering of memories in the Rök text) between Odin and Vafprúðnir in Vafprúðnismál, have been blocked by the interpretative tradition of identifying a reference to Theodoric the Great (Olsen 1921, 207-10, 222-24, cf. Bugge 1910, 238, and Lönnroth, 1977, 15). The relations we will map onto the Eddic mythology conform to the focus on local matters. We will also demonstrate that the over-all purpose of the Rök text echoes its opening lines: an attempt to put the death of a son in a meaningful context.

Guided by these principles we have been able to make consistent choices between the almost open-ended interpretative alternatives on different levels. The potential problem with our analytical perspective, of which we 
are well aware, is that it has the risk of exaggerating similarities, both with contemporary runic monuments and later ancient Scandinavian writings.

\section{Recontextualising the Rök runestone}

The Rök runestone was probably carved and erected at or close to what today is the site of the Rök church, to which the monument has given its name. The word rök means 'monolith' cf. Gotlandic rauk, a column-like sea stack, and the runestone was clearly impressive enough to denote the site of its placement, as well as later the parish and the church (cf. Andersson 1999, 1 with literature). It is reasonable to suggest that the stone, which shows all signs of being a memorial of high prestige, originally functioned as some kind of central marker at a gathering place, serving as a site for cult practices and funerals (cf. Williams 2013, 61-76 on high prestige runic monuments, and Nordberg 2003, 252-59 on funeral rites). The runestone could have had, we suggest, also a potential as an axis mundi; the site in the vicinity of the stone is simultaneously the symbolic center of heaven and earth, a place where one can pass from one cosmic zone to another, and communicate with the other world by means of religious rituals, making it a potential place of enlightenment (cf. Eliade 1987, 20-65).

Archaeological research shows that the area around Rök has been an intensive agricultural district for 6000 years, and its prosperity is manifested in several prominent sites for the religious practices of the ruling elite at different periods in time. Along the road between Rök and the Omberg mountain eight kilometers to the west lie Bronze Age burial mounds, and the weapon graves in the Smörkullen cemetery date to the Roman Iron Age (see Browall 2003). The region's prosperity was not, however, uninterrupted. A sudden decline in cultivation took place in the middle of the sixth century, when farms reverted to forests, and old settlements were forsaken (Widgren 1983). Data from ice-core sulphur layers in Greenland and Antarctica, supported by dendrochronological analysis, show that the decline in cultivation, a widespread phenomenon in the middle of the sixth century, was related to a series of volcanic eruptions 536-47 CE probably in North and Central America (Sigl et al. 2015, Toohey et al. 2016, Büntgen et al. 2016).

The impact on the climate of this series of severe volcanic events was dramatic, and is well attested to by data from all over the northern hemisphere, which shows abnormally cold summers for the period 536-50 CE (Charpentier Ljungqvist 2010, 2017). On the basis of the decline of cultivation, settlements, graves and other archaeological data, it has been esti- 
mated that the population of the Scandinavian peninsula decreased by $50 \%$ or more (Gräslund and Price 2012). The region around Rök was a highly specialized agricultural area, and seems to have had relatively low resilience (Widgren 1983, 2013).

At the time of the carving of the Rök runestone the socio-economic situation had recovered, but the extreme climate events had had pervasive effects. In the restructuring of farming after the climate crisis, social stratification had increased, and power seems to have been concentrated in the hands of a new type of leadership, legitimized by ritual assurance of good harvests, as well as military control of land (Löwenborg 2012, Andrén 2014). Claiming a special relation to Odin, the new ruling elite constructed themselves as necessary defenders against both real-life enemies, and destructive cosmic powers, since Odin was conceived of as a divine warlord engaged in the outcome of both human battles and the eschatological battle of Ragnarok, where he would lead divine and human warriors in a final encounter with the giants (Nordberg 2003, Sundqvist 2016).

It has in fact been argued that the specific motifs of Ragnarok show traces of the experience of the climate crisis (Gräslund 2007, Gräslund and Price 2012, Price and Gräslund 2015). Even if these eschatological themes as such are much older, they were most likely revitalized after the $536 \mathrm{CE}$ crisis (Hultgård 2017, 295, 396-415). It is also likely that these historical events affected the specific expression of the mythological themes.

Both Vafprúðnismál (st. 11-14, 20-25) and Voluspá (st. 3-6) start out from a state of cosmological balance established by Odin's act of creation and manifested by the regular rhythm of light. When the cosmological crisis is elaborated, four motifs are, according to the analysis of Gräslund and Price (2012, Price and Gräslund 2015), especially striking in relation to the extreme weather events after $536 \mathrm{CE}$.

- The idea of a fimbulvetr, a period of extreme cold preceding Ragnarok in Vafprúðnismál st. 44, also referred to as summers with svort... sólskin 'black sunlight' in Voluspá st. 40.

- The wolf Fenrir, one of the giants, who swallows the sun (hana Fenrir fari) in Vafprúðnismál st. $46 \mathrm{f}$., and whose whelp is called tungls tjúgari 'robber of a celestial body' in Voluspá st. 39.

- The rauðum dreyra 'red painting' of ragna sjot 'the dwellings of the gods' in VQluspá 40, compatible with the violently crimson skies of the northern hemisphere that have been reported after big eruptions of other tropical volcanoes such as Tambora 1815 and Krakatau 1883 (see Price and Gräslund 2015, 124). 
- The birth of the sun's daughter (Eina dóttur berr Álfroðull) in Vafprúðnismál st. $46 \mathrm{f}$., which can be connected to the longed-for return of the sun.

It is worth noting that the mythological solar events are presented in Vafprúðnismál with close parallels to what is related about the fate of Odin. Odin too is killed by the wolf (Úlfr gleypa mun Aldafoðr); and Odin also succeeds in begetting an offspring that warrants the final victory over the destructive powers, i.e. Víðarr who then avenges his father and kills the wolf (pess mun Viðarr vreka; Vafprúðnismál st. 53, cf. Voluspá st. 52 f.).

The age and distribution of the mythological conceptions presented in Vafprúðnismál and Voluspá cannot be determined conclusively, since the Icelandic manuscripts (as said above) date from the thirteenth century and later. However, the poems are taken to be among the most reliable sources for Norse mythology (Hultgård 2017, 73-75, 122). The motif of the wolf functions as a pars pro toto for the Ragnarok events in Eiríksmál (st. 7: nær ulfr inn hosvi sœekir á sjot goða 'when the grey wolf will attack the home of the gods'; Fulk 2012a, 1011) and Hákonarmál (st. 20: Mun óbundinn á ýta sjot Fenrisulfr fara 'The wolf Fenrir, unbound, will enter the abode of men'; Fulk 2012b, $192 \mathrm{f}$.) both dated to the tenth century. It is also alluded to in Sonatorrek(st. 13: mána bjarnar 'enemy of the moon' = Fenrisulfr, 24: ulfs of bági 'enemy of the wolf' = Odin, and 25: Tveggja bági 'enemy of the wolf' = Odin) the greatest of Norse elegies for a dead son (Einarsson 2003, 146-54) and a poem some scholars (e.g. Friesen 1920, 91) take for granted is composed by Egill Skallagrímsson himself in the tenth century. The spread of the motif of the wolf is evidently indicated also by somewhat later Viking Age runestones (cf. Källström 2016): e.g. the Norwegian Vang runestone (N 84) which shows the wolf swallowing the sun, the Ledberg runestone in southeastern Sweden (Ög 181) and the Andreas III stone on the Isle of Man (Barnes 2019, 101 and 270) where the wolf devours Odin, as well as three runestones in southern Sweden with other wolf motifs (DR 271 Tullstorp church, DR 284 Hunnestad 3 and the lost DR 286 Hunnestad 5). Moreover, it should be noted that the inscription of the Skarpåker runestone (Sö 154), raised to the memory of a dead son, seems to echo an expression from the third stanza of Vqluspá when it proclaims the end of the world: 'Earth shall be riven and High Heaven' (cf. Hultgård 2017, 179-83, 390-93).

That rulers were supposed to serve Odin after death in the battle of Ragnarok is clearly indicated by Eiríksmál and Hákonarmál, which tell of the adoption of king Eiríkr and king Hákon respectively into the group of Odin's warriors which parallels the circle of warriors around the earthly 
ruler, for example referred to as ýtar and einherjar in Vafprúðnismál st. $40 \mathrm{f}$. The conditions for this posthumous mission were noble descent (i.e. belonging to the ruling class), a suitable death (i.e. in battle), and a ritually proper funeral ceremony, with this final practice appearing to have had the potential to compensate for an ordinary, non-violent death (Nordberg 2003, 120-36). One part of the funeral rituals might have been the enigmatic questions whose answers were known only by a select few, including the dead (Price 2010, 145). Vafprúðnismál seems to preserve some traits from this ritual context: its location in the hall of Vafprúonir, and the ending of the poem, where Vafprúðnir in stanza 54 is asked: hvat mælti Óðinn, áðr á bál stigi, sjálfr i eyra syni? 'what whispered Odin in the ear of his dead son before he was carried to the pyre?' (cf. Schjødt 2008, 338).

The eschatological themes of Ragnarok and the memory of the $536 \mathrm{CE}$ crisis, passed down through the centuries, may have been reactivated at the time of VāmōðR's demise, partly by his death itself. Identifying the other factors that could have contributed depends on the dating of the monument. Three extraordinary events around the time should be taken into consideration: the strongest known solar storm in $775 \mathrm{CE}$, with documented dramatic red skies (Sukhodolov et al. 2017); the exceptionally cold summer of 775 CE (Sigl et al. 2015); and the almost total solar eclipse in $810 \mathrm{CE}$, which would have given the impression that the sun was extinguished shortly after dawn (Espenak and Meeus 2006).

\section{The structure of the inscription}

The Rök runestone inscription consists of twenty-eight lines, of which twenty are vertical and eight more or less horizontal. We concur with the scholarly consensus that suggests that the reading should start with the two vertical lines that mention the son Vāmōðr and his father Varinn (side A, lines 1 and 2 in fig. 1), and continue with the next seven vertical lines from left to right (side A, lines 3-8 and side B, line 11), only interrupted by the reading of the two horizontal lines when this is demanded by the syntax of the inscription (lines 9 and 10). We take this way of reading as a key to the much debated reading order of the back $(\mathrm{C})$, the second narrow side (D) and the top side (E).

Thus, we propose that the reading should continue with vertical lines from left to right, with the interruption of horizontal lines where this is necessary for syntactical reasons. This means that the reading of the back (C) must start with the horizontal line below (line 12), before the eleven last vertical lines can be read (lines 13-23) until the counterclock- 

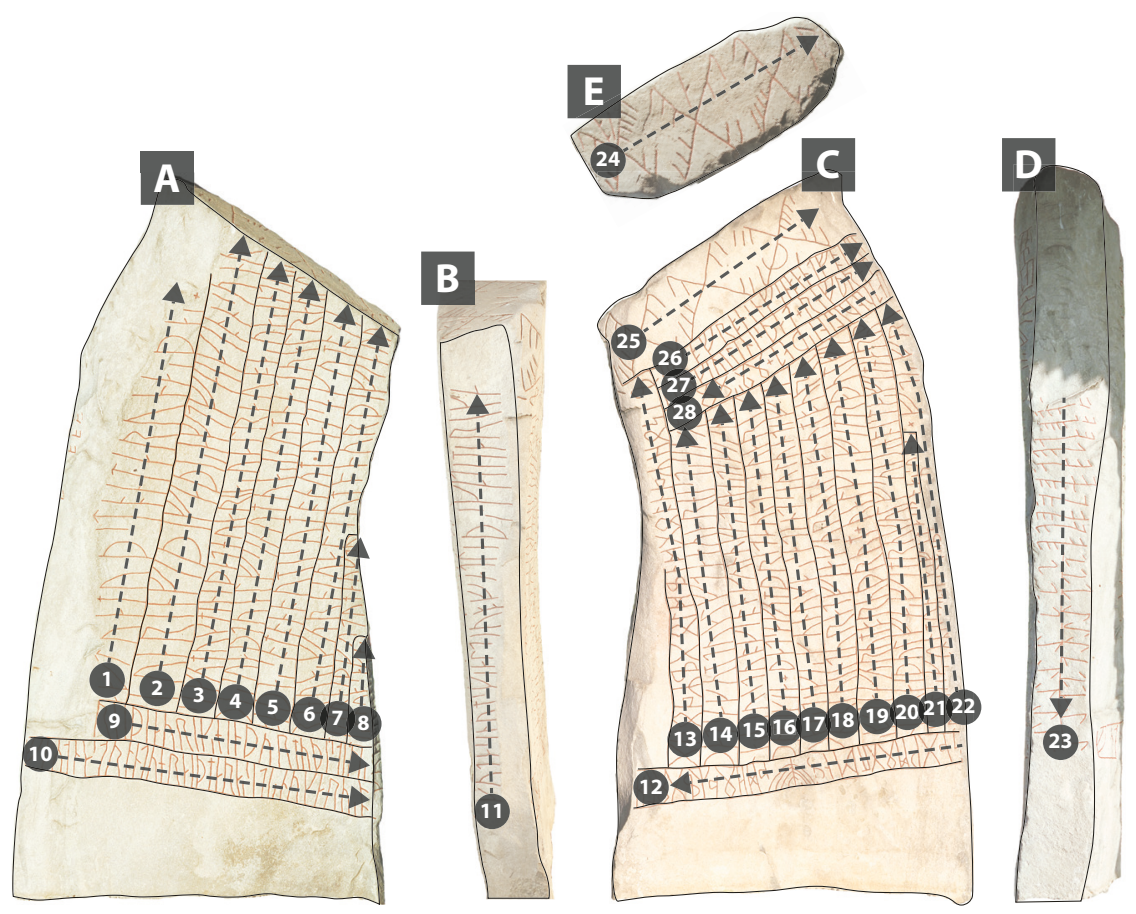

Fig. 1. Reading order of the Rök runestone (numbers) and reading directions (arrows). Illustration by Marco Bianchi (CC BY) and photos by Bengt A. Lundberg, Swedish National Heritage Board (CC BY).

wise circle around the stone is completed with the last vertical line (23) on the second narrow side (D). Since the narrow side is connected to the top side $(\mathrm{E})$, the five remaining horizontal lines on the top side and the upper part of the back are most easily read from above (lines 24-28). The new numbering of lines is given in fig. 1 . The dotted arrows indicate the reading direction of each line.

The inscription can thus be seen to be structured in six passages, when the reading order proposed above is combined with the observation of orthographic changes. The inscription starts with large short-twig runes (lines 1-2), and continues with smaller short-twig runes (3-11), runes in older futhark (12-13), and then another set of short-twig runes (14-22). Thereafter come numerical ciphers (23-25), followed by lines which partially involve a substitution cipher (26-28). The ten last runes (the second half of line 28) are read as a numerical cipher in the same reading direction as the first part of the line. The division of these passages is shown in fig. 2. 


\begin{tabular}{|c|c|c|c|c|c|c|}
\hline A: $1-A: 2$ & A: $3-B: 11$ & $\begin{array}{l}\text { C: } 12- \\
\text { C: } 13\end{array}$ & $\begin{array}{l}\text { C: } 14- \\
\text { C: } 22\end{array}$ & $\begin{array}{l}\text { D: } 23, \\
\text { E: } 24, C: 25\end{array}$ & $\begin{array}{l}\text { C: } 26- \\
\text { C: } 28\end{array}$ & $\begin{array}{l}\text { C: } 28 \text { The } \\
\text { ten last } \\
\text { runes }\end{array}$ \\
\hline $\begin{array}{l}\text { Short-twig } \\
\text { runes; } \\
\text { large size }\end{array}$ & $\begin{array}{l}\text { Short-twig } \\
\text { runes }\end{array}$ & $\begin{array}{l}\text { Runes } \\
\text { from older } \\
\text { futhark }\end{array}$ & $\begin{array}{l}\text { Short-twig } \\
\text { runes }\end{array}$ & $\begin{array}{l}\text { Numerical } \\
\text { cipher }\end{array}$ & $\begin{array}{l}\text { (Partially) } \\
\text { substitu- } \\
\text { tion cipher }\end{array}$ & $\begin{array}{l}\text { Numerical } \\
\text { cipher }\end{array}$ \\
\hline $\begin{array}{l}\text { Memory } \\
\text { of the } \\
\text { dead son }\end{array}$ & $\begin{array}{l}\text { Memory of } \\
\text { the light }\end{array}$ & $\begin{array}{l}\text { Memory } \\
\text { of the } \\
\text { sacrifice } \\
\text { for light }\end{array}$ & $\begin{array}{l}\text { Memory of } \\
\text { the battle } \\
\text { between } \\
\text { the powers }\end{array}$ & $\begin{array}{l}\text { Last } \\
\text { memory of } \\
\text { the light }\end{array}$ & $\begin{array}{l}\text { Last } \\
\text { memory of } \\
\text { the battle } \\
\text { between } \\
\text { the powers }\end{array}$ & Summary \\
\hline $\begin{array}{l}\text { Statement; } \\
\text { Statement }\end{array}$ & $\begin{array}{l}\text { Question 1; } \\
\text { Question 2; } \\
\text { Statement; } \\
\text { Statement }\end{array}$ & Question 3 & $\begin{array}{l}\text { Question 4; } \\
\text { Question 5; } \\
\text { Statement; } \\
\text { Statement? }\end{array}$ & $\begin{array}{l}\text { Demand; } \\
\text { Demand; } \\
\text { Question 6; } \\
\text { Question } 7\end{array}$ & $\begin{array}{l}\text { Demand; } \\
\text { Question 8; } \\
\text { Statement; } \\
\text { Question 9; } \\
\text { Statement }\end{array}$ & \\
\hline
\end{tabular}

Fig. 2. Structure of the Rök runestone inscription

The inscription is characterized by great diversity at micro level, but at the level of passages there is noticeable uniformity: all six passages are constructed as memories. In the first passage, this is accomplished linguistically in a typical way by use of the phrase aft Vāmōo 'after Vāmōðr'. Each of the following passages refers explicitly to itself as a memory (minni). This is done only once in each passage, either in its first clause, or in one case, in the final (the damaged line 22). These memories concern cosmological events, as we will argue, and provide a setting for Vāmōðn's demise. While the standard linguistic interpretation has been that minni is part of a compound denoting 'folk memory' (mōgminni), we read the phrase as a reminder that it is ritually related to Odin, the god of enigmatic knowledge: Ygg minni 'a memory for Yggr' (Nordenstreng 1912). The name Yggr, meaning 'the terrible one', is a byname for Odin, and is for example used when he enters the hall of Vafprúðnir to begin the wisdom contest in Vafprúðnismál st. 5: inn gekk Yggr pegar 'Yggr went in at once'. Thus, the concept of memory should not only be understood in its ordinary sense as a recollection of the past, something of which the people who read the inscription are reminded. Instead, these memories are ritual acts of social and religious significance relating to the past, present, and future, that together contribute to the maintenance and renewal of the world (cf. Lincoln 1986). The alternation between present and past tense throughout the Rök text should be seen in this light. It is also important to 
notice that the memories, if only viewed as text passages, are incomplete. They are completed only through the efforts of readers.

Each passage is formed as a complex of speech acts (with the exception of the passage constituted by question 3 , see fig. 2). These complexes invite readers to respond, thus completing the memories. Especially striking is the use of questions, which prompt the reader to contribute information. Altogether, the inscription contains nine questions. Grammatically, they are realized in three different ways. The first five questions are expressed in clause complexes with an initial plural imperative (sagum) followed by an embedded interrogative clause (hværiar ..., etc.): Sagum ... pat, hværiar valraubar $v \bar{a}_{R} i_{n} t v \bar{a}_{R} p \bar{a}_{R} \ldots$. ?, 'Let us say this ... which spoils of war there were two ...?' (etc.). The following questions use a more economic grammar, either the free interrogative clause: 'To whom is born an offspring?', or in three cases the elliptic alternative to leave out 'who(m) (is)'. The latter grammatical strategy has prevented previous researchers from identifying these passages as semantic questions, though this elliptic grammar is attested to in the context of Scandinavian riddles (cf. e.g. Ström 1939, $171 \mathrm{f}$.). The structure of the inscription is summarized in fig. 2 .

\section{The interpretation of the inscription}

Our interpretation is given in Early Old Norse transcription and English translation in fig. 3. In the following sections we will comment on each passage, supplemented by a transliteration, and point out some crucial relations to other Old Norse texts.

Memory of the dead son: the first passage

\section{aft uamup stanta runar par $+\langle i\rangle \mathrm{n}$ uarin fapi fapir aft faikign sunu ${ }^{2}$}

Aft Vāmṑ stãnda rūnar pār. Æ̇n Varinn fāði, faðir, aft faigiãn sunu.

After Vāmōðr stand these runes. And Varinn, the father, made them after the death-doomed son.

The Rök inscription begins in a not unexpected manner, i.e. with a memorial formula. It states that the runic monument commemorates a son,

${ }^{2}$ Since both older and younger futhark runes are found on Rök we transliterate $k$ as $\mathbf{q}, \boldsymbol{\beta}$ as

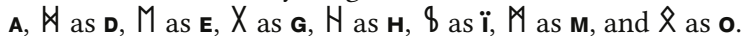




\begin{tabular}{|c|c|c|}
\hline Q. & Early Old Norse transcription & English translation \\
\hline & $\begin{array}{l}\text { Aft Vāmōō stãnda rūnaR pāe. ÆEn } \\
\text { Varinn fāði, faðir, aft faigiãn sunu. }\end{array}$ & $\begin{array}{l}\text { After Vāmōðr stand these runes. And Varinn, } \\
\text { the father, made them after the death-doomed } \\
\text { son. }\end{array}$ \\
\hline 1 & 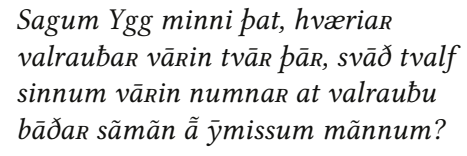 & $\begin{array}{l}\text { Let us say this as a memory for Ygge, which } \\
\text { spoils of war there were two, which twelve } \\
\text { times were taken as spoils of war, both from } \\
\text { one to another? }\end{array}$ \\
\hline & 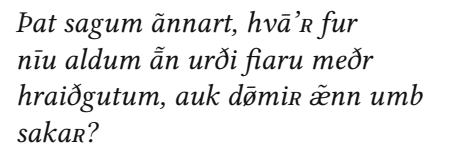 & $\begin{array}{l}\text { This let us say as second, who nine } \\
\text { generations ago lost their life with the } \\
\text { Hraiðgutar [i.e. in the east]; but still decides } \\
\text { the matter? }\end{array}$ \\
\hline 2 & $\begin{array}{l}\text { Raið iau, rinkR hinn purmōði, } \\
\text { stilliR flutna, strãndu Hraiðmarar. } \\
\text { Sitis nū garuR ã guta sīnum, } \\
\text { skialdi umb fatlaðR, skati mǣringa. }\end{array}$ & $\begin{array}{l}\text { Ride the horse did the bold champion, chief } \\
\text { of men, over the shores of the Hraiðsea [i.e. } \\
\text { over the eastern horizon]. Now he sits armed } \\
\text { on his horse, his shield strapped, foremost of } \\
\text { the famous. }\end{array}$ \\
\hline 3 & 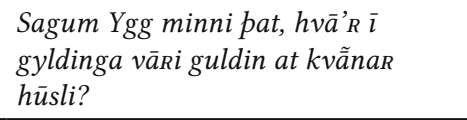 & $\begin{array}{l}\text { Let us say this as a memory for YggR, who } \\
\text { because of a howler [i.e. wolf] has suffered } \\
\text { through a woman's sacrifice? }\end{array}$ \\
\hline 4 & 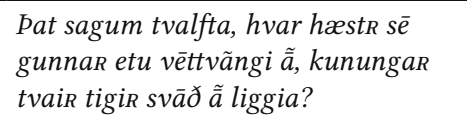 & $\begin{array}{l}\text { This let us say as twelfth, where the horse } \\
\text { of the battle [i.e. the wolf] sees food on the } \\
\text { battlefield, where twenty kings lie? }\end{array}$ \\
\hline 5 & 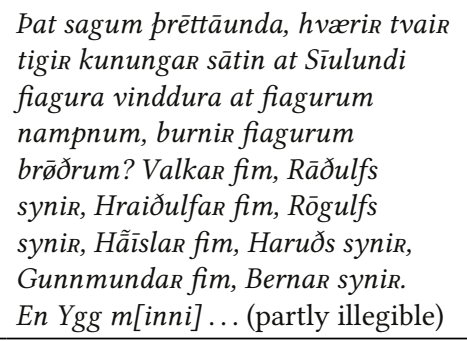 & $\begin{array}{l}\text { This let us say as thirteenth, which twenty } \\
\text { kings were at the Grove of Sparks [i.e. the } \\
\text { battlefield] in four directions, of four names, } \\
\text { born of four brothers? } \\
\text { Five Valkis, sons of RāðulfR, five HraiðulfRs, } \\
\text { sons of RōgulfR, five Hẫisls, sons of Haruðr, } \\
\text { five GunnmundRs, sons of Bern. } \\
\text { And for YggR a m(emory) ... }\end{array}$ \\
\hline & Sagum Ygg minni: por! & Let us say a memory for YggR, dare! \\
\hline 6 & Sibi vīaværi? & $\begin{array}{l}\text { [Who is] a protector of sanctuaries for a } \\
\text { brother? }\end{array}$ \\
\hline 7 & $\bar{O} \operatorname{lni} r \bar{y} \partial_{R} ?$ & $\begin{array}{l}\text { [Whom] does the ravager [i.e. the wolf] } \\
\text { redden with blood? }\end{array}$ \\
\hline 8 & $\begin{array}{l}\text { Sagum Ygg minni, } \\
\text { (h)vaim sē burinn niðr, dræ̃ngi! Villi } \\
\text { nè's pat. }\end{array}$ & $\begin{array}{l}\text { Let us say a memory for YggR, } \\
\text { to whom is born an offspring, to the young } \\
\text { man! It is not a lie. }\end{array}$ \\
\hline 9 & $\begin{array}{l}\text { Knūã knātti iatun? Villi nèe’s pat. } \\
\text { (H)nit. }\end{array}$ & $\begin{array}{l}\text { [Who] could beat a giant? It is not a lie. } \\
\text { Clash! }\end{array}$ \\
\hline
\end{tabular}

Fig. 3. Interpretation and translation of the Rök runestone inscription. (Q. = Question.) 
Vāmōðr, and that his father, Varinn, made the runes (or possibly caused them to be made). Two details should be noticed: the word for 'runes' in the first line, and the unusual word for 'dead' in the second.

Since 'these runes' (rünar $p \bar{a} R$ ) aims at the message of the whole inscription it frames the passages to come. The word rünar can also mean '(secret) knowledge', as in Vafprúðnismál st. 42, and would then more specifically refer to the memories of the inscription and its questions. The present tense anticipates that the memory of the son will be preserved through any crisis as long as there are humans, or gods, to read the runes and complete the memories by providing the knowledge asked for.

The adjective for 'deceased' in the second statement is faig $R$ (English fey), which usually means 'fated to die' or 'marked to die' (cf. Vafprúðnismál st. 55) but seemingly means just 'dead' in Voluspá st. 40. There, it may well have been chosen only to alliterate, and the same could be true on Rök (cf. $f \bar{a} \partial i$ and $f a ð i R$ ). On the other hand, as Vāmōðr was likely part of the ruling elite, his death could have been conceived as determined by Odin in preparation for a new important mission.

Memory of the light: the passage with questions 1-2

sakum uk mini pat huariar ualraubar uarin tuar bar suap tualf sinum uarinumnar

\section{t ualraubu bapar saman q umisumanum}

' pat sakum gnart huar fur niu altum gn urpi fiaru mir hraipkutum auk tumir an ub sakar

raip iau rike hin purmupi stilin flutna strantu hraipmaras sitie nu karuR g kuta sinum skialti ub fatlapr skati marika

Sagum Ygg minni pat, hværiaR valraubaR $v \bar{a}_{R}$ in $t v \bar{a}_{R}$ pa $\bar{a}_{R}$, svāð tvalf sinnum vārin numnar at valrauђu bāðar sãmãn ã $\bar{y}$ missum mãnnum?

Pat sagum ãnnart, hvā's fur nīu aldum ã̃ urði fiaru meðr hraiðgutum, auk dø̄mir $\tilde{x} n$ umb sakar?

Raið iau, rinkR hinn purmōði, stilliR flutna, strãndu Hraiðmarar. SitiR nū garuR ã guta sinum, skialdi umb fatlaðR, skati mæ̈ringa.

Let us say this as a memory for YggR, which spoils of war there were two, which twelve times were taken as spoils of war, both from one to another?

This let us say as second, who nine generations ago lost their life with the Hraiðgutar [i.e. in the east]; but still decides the matter? 
Ride the horse did the bold champion, chief of men, over the shores of the Hraiðsea [i.e. over the eastern horizon]. Now he sits armed on his horse, his shield strapped, foremost of the famous.

We do not see any reference to Theodoric in this passage, as has previously been suggested. Line 9 is traditionally interpreted as rēð Piōðrīk $k_{R}$ hinn pur$m \bar{o} ð i$ and understood to mean 'rule did Theodoric the bold'. Instead, we follow Ralph $(2007,150-53)$ in reading it as raið iau, rinkR hinn purmōði 'ride the horse did the bold champion', with allitteration on reið and rink

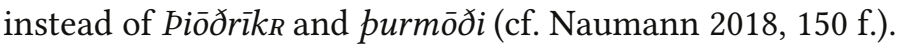

The questions are: Which 'spoils of war' are referred to in the first question, and who died in the second? We agree with Ralph $(2007,143)$ that the passage thematizes the rhythm of light: the exchange of the spoils of war is the interplay between the moon and the sun, and the one who died, but still lives, is the sun. ${ }^{3}$ Mentioning the sun and the moon references the world's creation, but also its immanent instability and fated end, echoing the downfall of Vāmōðr and suggesting his purpose in the afterlife.

The scene staged by the first question is that of a mutual wartime plunder that plays out twelve times between two apparently evenly matched forces, and following Ralph it refers to the twelve lunar cycles contained in one year. It is light that is taken from the sun by the moon until it becomes full, and light that is then plundered again by the sun, until the moon wanes completely. Ralph points out that a riddle with similar content is attested to in Old English poetry (p. 142 f.; riddle 27, see Williamson 1977, 85).

It is also important to point out that both Vafprúðnismál and Vqluspá are concerned with the cosmological rhythm of light, before they turn to the events surrounding the end of the world. The metaphor of war indicates a dimension of menacing instability in the cosmological balance, a central theme of Old Norse mythology. There are however no other Old Norse sources for the idea that the rhythm of light is an ongoing conflict between moon and sun. Vafprúðnismál st. 23 mentions that they are brother and sister, and that himin hverfa pau skulu hverjan dag oldum at ártali 'they shall disappear from heaven every day, to measure years for

\footnotetext{
${ }^{3}$ The sequence huar is either the masculine $h v a R(>h v \bar{a} R)$ form of the Runic Swedish interrogative pronoun (Peterson 2006, 25) which has a defective paradigm (cf. Seip 1931). The nom. fem. sing. form is otherwise unattested but must of course have existed and should phonetically have been either * $h u$ (cf. Gothic $h \bar{o}$ ) or analogically * $h v \bar{a}$. In the former case the relative pronoun must be Runic Swedish æR or $a_{R}$ (cf. Peterson 2006, s.v. es, and Noreen 1904 , $§ 512$ Anm. 1), in the latter we must posit an enclitic ' ${ }_{R}$ (cf. Peterson, 2006, s.v. es). We have somewhat arbitrarily chosen $h v \bar{a}{ }^{\prime}$.
} 
people', but does not suggest that they rob the light from each other. Yet, Ralph's convincing suggestion must result in a new approach when interpreting the rest of the Rök text, although not necessarily in the direction he follows.

The metaphor of dying in the second question has been seen as a metaphor for the daily sunset (implicitly in Ralph 2007, explicitly in Holmberg 2016, 90). For two reasons, however, the death referred to here seems to point towards a specific historical, cosmic event, rather than alluding to the recurrent sunset. First, it is said to be a death 'with the Hraiðgutan' which is a poetic expression for an event to the east (i.e. at dawn), and not westwards (cf. Holmberg 2016, 89 f.). Second and most important, the event is temporally specified to 'nine generations ago' (fur niu aldum). Given the current dating of the inscription to around $800 \mathrm{CE}$ and an approximation of each generation to thirty years, the event alluded to would have happened in the early sixth century. Thus, the climate crisis from $536 \mathrm{CE}$ turns out to be an obvious candidate for this "death" of the sun, when it failed to rise in the east. Two hundred and seventy years is a long time indeed, but a memory of nine generations does not seem unreasonable. The runestone at Norra Sandsjö (Sm 71) gives the names of six generations (Jansson 1987, 101). It might also be significant that the number nine had a strong symbolic meaning of fulfilment. The most well-known example is Hávamál st. 138 (see Sundqvist 2010, 68-96). If Vāmōðr was the ninth in the line of his kin since the death of the sun, his demise could have provoked the idea of a new menace. The conclusion of the question seems to remind the reader that the rhythm of light was re-established. The wording 'still decides the matter' (dø̄mir æ̃nn umb sakar, Höfler 1952, 39, Lönnroth 1977, 25 f., Widmark 1992, 35) then alludes to the sun's renewed presence.

The message of two statements in the end of the passage comprising a stanza of the Old Norse verse form fornyrðislag is clear. The sunlight still prevails, and its path over the firmament is compared to a horse and rider. The most striking parallel is found in Vafprúðnismál st. 12, although this stanza focuses on the horse of the daylight-rider:

Skinfaxi heitir, / er inn skíra dregr / dag um dróttmogu; / hesta beztr / pykkir hann með / Hreiðgotom /

Skinfaxi is called who draws/carries the bright day to humanity; the best of horses he is considered among Hreiðgotar.

Two similarities are obvious. The personified sunlight is referred to in the shape of a rider or charioteer (called Dagr in Vafprúðnismál st. 25 and 
elsewhere). ${ }^{4}$ Secondly, both texts mention the Hreiðgotar. The motivation for this reference in Vafprúðnismál seems to be that the Hreiðgotar live closer to where the sun rises and thus get the best opportunity to value the sun-horse. Accordingly, we suggest that riding over 'the shores of the Hraiðsea' (strãndu Hraið[guta]maraR) is a poetic expression for daybreak (cf. Holmberg 2016, 89 f.). Another detail to be noted is the repeated idea that the riding champion is the superior one in a circle of other men or heroes (stillir flutna, 'chief of men' and skati mæ̈ringa, 'foremost of the famous'). A clue to their identity seems to be the greeting phrase in Sigrdrífumál st. 4, used by a valkyrie: Heill dagr! Heillir dags synir! 'Hail, day! Hail, sons of day!' (Jónas Kristjánsson and Vésteinn Ólason 2014, 2: 314). One idea expressed in the Rök stanza may be that Dagr is the one who gathers all men for the fight against destructive powers, since he wakes them up in the morning. It should also be noted that deglingar is a word for 'kings', descendents of the deity Dagr; it is used also in Hákonarmál st. 9 for the death-doomed kings.

\section{Memory of the sacrifice for light: the passage with question 3}

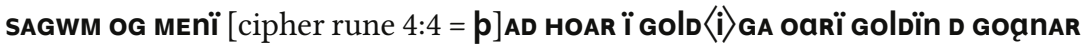
Hoslï [see note 3 concerning the transliteration here]

\section{[= sakum uk mini pat huar i kultika uari kultin t kugnar husli]}

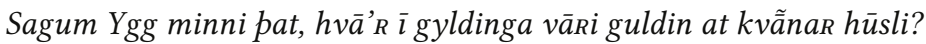

Let us say this as a memory for YggR, who because of a howler [i.e. wolf] has suffered through a woman's sacrifice?

In this most difficult passage, never interpreted satisfactorily, the sequence ï GolD $\langle\mathbf{i}\rangle$ GA (lines 12 and 13) demands a construction not known from other sources. The standard interpretation has been - with inspiration

\footnotetext{
${ }^{4}$ We should point out that the rider in the Rök inscription is not explicitely referred to as 'he' although an English translation forces a gender choice. We posit that we are still dealing with Sól, who has however been given masculine-gendered epithets. Female deities are referred to as guð (originally neuter plural, later masculine singular) - Skaði is called ondurguð 'ski-god' (Faulkes 2005, 24) - and Eir is referenced to as a masculine-gendered læknir beztr 'best physician' (p. 29). Also, even the shield has a parallel in Grímnismál st. 38: Svalinn heitir, hann stendr sólu fyrir, skjoldr skinandi goði 'Its name is Svalinn, it, the shield, stands before the sun, the shining god' (Jónas Kristjánsson and Vésteinn Ólason 2014, 1: 375). It is also possible that Dagr here assumes Sól's function. It would in many respects rhyme better if Dagr is seen as the hypostasis of Sól, at least in the Rök context, but this is admittedly a weaker link in our chain of reasoning. Perhaps future research will resolve the matter.
} 
from Ingvaldstorp, the name of a nearby village - to render the sequence as Inguldinga, which would then mean 'the line of IngivaldR'. A better guess would be to interpret the sequence as $\bar{l}$ gyldinga, 'because of a howler' i.e. a wolf. ${ }^{5}$ Gyldir is in Old Icelandic an attested word for wolf. The derivation -ing $(i)$ is the same as in the putative Inguldinga and it is also used in another synonym for wolfs: heiðingi, literally meaning 'the one from the heathland'.

The memory is then completed by the identity of someone suffering through the sacrifice of a woman to a wolf. That Sól suffers through the sacrifice of herself has such a third-person self-reference parallel in a lausavisa by Skúli Porsteinsson, where she is both called Glens beðja "bedmate of Glenr" and said to stride í vé gyðju "into the goddess's [i.e. her own] sanctuary" (Heslop 2017, 367). We propose that the answer to the question of this passage (once again) is the sun (Sól). Before the sun is killed by the wolf Fenrir at the beginning of the Ragnarok battle, she gives birth to a daughter. This dramatic event, possibly related to the return of the sun after $536 \mathrm{CE}$, is the first step in a cosmological transformation. This world will perish, but the battle between the gods and the destructive forces, including Fenrir, will give rise to a new world where Sól's daughter will shine.

In one version of Hervarar saga a sun riddle is asked: Hvat er pat undra ... lýðum lýsir, en loga gleypir ok keppast um at vargar ávalt? "What wonder is that ... it gives light to men, but swallows flame, and wolves strive after it always?" (Burrows 2014, 121). Vafprúðnismál offers an even closer parallel. It is the answer given in the wisdom contest to the question about the fate of the sun (st. 47):

Eina dóttur / berr Álfröðull, / áðr hana Fenrir fari; / sú skal ríða, / pá er regin deyja, / módur brautir, mǽr.

A daughter Álfröðull [the sun] gives birth to, before Fenrir [i.e. the wolf] catches her up; she [i.e the daughter] will ride, when the gods die, the maiden on her mother's roads.

The interpretation explains why the sacrifice should be "because of a howler' (i gyldinga) i.e. because of the wolf. That the wolf is referred to as the 'howler' recalls the idea that Fenrir howls (grenjar) when he is bound

${ }^{5}$ The Old Icelandic preposition $i$ governing the accusative can have the (admittedly rare) meaning "die ursache oder den zweck einer handlung bezeichend" ['denoting the cause or goal of an act'] (Gering 1903, 526). 
according to Gylfaginning (Faulkes 2005, 29) and is reminiscent of the ominous barking (Geyr nú Garmr) at Ragnarok in Voluspá st. 43, 47, and 56.

The choice of runes from the older futhark is noteworthy, as this was the script used 'nine generations ago'. This is appropriate for a reference to the happy return of the sun after the years of darkness from $536 \mathrm{CE}$. In the mythological conception of time, Ragnarok has already started, and so has the new creation.

Memory of the battle between the powers: the passage with questions 4-5

pat sakum tualfta huar histr si kunar ituitugki gn kunukar tuair tikir suap a likia

+ pat sakum pritaunta huarir tuair tikir kunukar satin t siulunti fiakura uintur at fiakurum nabnum burn $\langle i\rangle_{R}$ fiakurum bruprum

+ ualkar fim râpulfsunir hraipulfar fim rukulfsunir haislar fim harups sunir kunmuntar fim ḅirnar sunir

nuk m--- ṃ-- alu --ḳ̣ ainhuar -p.....p ... × ftir fra

Pat sagum tvalfta, hvar hæstr sē gunnar etu vêttvãngi $\tilde{a}$, kunungar tvair tigiR svāð ã liggia?

Pat sagum prēttāunda, hværiR tvair tigis kunungas sātin at Sīulundi fiagura vinddura at fiagurum nampnum, burniR fiagurum brø̄ðrum?

Valkar fim, Rāðulfs synir, Hraiðulfar fim, Rōgulfs synir, Hã̄islar fim, Haruðs synir, Gunnmundar fim, Bernar synir.

En Ygg $m[$ inni] ... (partly illegible)

This let us say as twelfth, where the horse of the battle [i.e. the wolf] sees food on the battlefield, where twenty kings lie?

This let us say as thirteenth, which twenty kings were at the Grove of Sparks [i.e. the battlefield] in four directions, of four names, born of four brothers?

Five Valkis, sons of RāðulfR, five Hraiðulfrs, sons of RōgulfR, five Hāīsls, sons of Haruðr, five Gunnmundrs, sons of Bern.

And for YggR a m(emory) ... [last line partly illegible]

When encountering the next memory, the reader is moved from the heavens to the battlefield, still following the same enemy, the wolf. The new pair of questions asks for the place where twenty kings lie, and their identity. We suggest that the inscription has taken a narrative leap to 
the end of Ragnarok which would also explain the mysterious jump to mentionings of the 'twelfth' and 'thirteenth', just as mythological motifs leap in and outside of the twelve numbered stanzas in Vafprúðnismál. The place is the battlefield where Odin together with his warriors and the rest of the gods will meet the wolf Fenrir and the other giants, and the twenty kings can probably be seen as representing Odin's warriors. The scene establishes the purpose of VāmōðR's death: that he is to take part on Odin's side in the final battle of the powers.

In question 4 the phrase hæstr gunnaR (lines 14 and 15) has traditionally been construed as the 'horse of [the valkyrie] Gunnr' and interpreted as a kenning for 'wolf'. We accept the interpretation, but read gunnar not as the name of the valkyrie, but more plainly as 'battle', (cf. e.g. gunnar haukr 'the hawk of the battle' for raven, another battlefield scavenger, in Hrómundr halti Eyvindarson's Lausavísa 1, in Jónsson 1912, 90, cf. Holmberg 2016, 95). Nevertheless, it would be more straightforward to interpret hvar hæstr sē gunnar etu vēttvãngi $\tilde{a}$ as 'where the horse sees battle food on the battlefield'. This presupposes that hæstR alone can stand for 'wolf'. That indeed seems to be the case when the giantess Hyrrokkin's steed, a wolf, twice is called just hestr 'horse' (Faulkes 2005, 46). On the other hand, 'battle's food' would not be an expected kenning as the subjective genitive usually is that of a predator, cf. arnar matr "food of the eagle [CORPSES]" in a half-stanza by Einar Skúlason (Gade 2017, 159).

In question 5 we do not accept the idea that the sequence $\mathbf{t}$ siulunti fiakura uintura (lines 17 and 18) carries any information about the stay of these kings on Zealand for four winters. As the scene is the final battlefield, called Vígríðr (Vafprúðnismál st. 18) but also Óskópnir in Eddic poems (Fáfnismál st. 15; Jónas Kristjánsson and Vésteinn Ólason 2014, 2: 306), we propose that SiulundR 'the Grove of Sparks' is simply an East Norse variant. (The fight did not take place in a wood or copse of trees but on a field or plain named after a nearby grove.) We follow, with some hesitation, the interpretation of vinddura as referring to the four points of the compass (Pipping 1932, 50-52, cf. Ralph 2007, 155).

Both questions have parallels in Vafprúðnismál. In the poem (st. 17 f.) Odin is asked about the place for the final battle between giants and gods. He gives the name of the battlefield (Vígriðr) and adds that: hundrað rasta hann er á hverjan veg 'it is a hundred miles in every direction' (st. 18). Later (st. $40 \mathrm{f}$.) Odin asks a question about a group of men who practice fighting daily, and Vafprúðnir is able to give the answer: Odin's warriors (the einherjar). In the wisdom contest of Vafprúðnismál these questions are, on the surface, neutral questions about mythological knowledge. In 
the Rök inscription the questions are a snapshot of a critical moment in the battle, when the wolf catches sight of Odin's warriors, now seemingly defenseless or dead, and intends to devour them. There are other descriptions that focus on the run-up to this clash, e.g. er Oððinn ferr við úlf vega 'when Odin fares to fight with the wolf' (Voluspá st. 52) and átta hundruð einherja ganga senn ór einum durum pá er peir fara at vitni at vega 'eight hundred einherjar go through each door [of Valhalla] at the same time when they fare to fight the wolf' (Grímnismál st. 23, Jónas Kristjánsson and Vésteinn Ólason 2014, 1: 372). A crucial passage is the argument given by Odin himself to explain the death of king Eírikr in Eiríksmál st. 7: it is unknown when the grey wolf will run towards the dwellings of the gods (see above). In other words, the reason for king Eírikr's death is that Odin needs to let warriors die in order for them to be present at the fight against the wolf at Ragnarok.

In the case of Eiríksmál, six kings are presented as a new group of warriors for the final battle in a way that might be a relevant parallel since this group of brothers-in-arms is organized in the same way as each unit in the Rök inscription. The list of names in the Rök inscription ('five Valkis, sons of Rāðulfr' etc.) is structured $(5+1)+(5+1)+(5+1)+(5+1)$. King Eiríkr presents his group of warriors in a similar way $(5+1)$ in Eiríksmál 9: Konungar eru fimm; kenni ek pér nafn allra; ek em inn sétti sjalfr. "There are five kings; I shall identify for you the names of all; I am myself the sixth" (Fulk 2012a, 1003). Unfortunately the poem breaks off at this point.

The twenty kings in the Rök text belong to four groups of brothers who are mentioned under the same name: five Valkis, five Hraiðulfrs, five Hāisls, and five Gunnmundrs, although this likely refers only to the oldest brother in each group (Olrik in Bugge 1910, 259-61). The inscription also gives the names of the father of each unit-RāðulfR, RōgulfR, Haruðr, and Bern - who, in turn, are brothers. It should be noted that in Hákonarmál st. 16 the king is said to have eight brothers waiting for him among the warriors in Valhalla: pú átt inni hér átta brőd "you have eight brothers in this place" (Fulk 2012b, 190). The carver of the inscription has obviously done his utmost to accommodate all of the names on the stone, which suggests that there is something important about them. These names may perhaps have a battle-related meaning (Lönnroth 1977, 33-36).

Unfortunately, we lack the clue which was probably given in the final, now damaged line of the passage. The first four runes nukm can be the beginning of a variant of the memory-formula found in other passages: En Ygg m(inni) 'And for YggR a m(emory)'. But the meaning of the whole speech act cannot be reconstructed. 
Last memory of the light: the passage with questions 6-7

[cipher runes - 2:4 3:6 3:2 1:3 3:2 3:6 1:3 2:3 2:2 2:3 3:3 3:2 3:5 = -akum uk mini pur]

[cipher runes 2:5 2:3= si]bi [cipher runes 3:2 2:3= ui] a[cipher runes 3:2 2:4= ua]ri

[cipher runes 3:3 1:4 2:2 2:3 3:5 3:2 = ulni ru]pR

Sagum Ygg minni: por!

Sibi vīaværi?

$\bar{O} \ln i \mathrm{r} \bar{y} \partial_{R}$ ?

Let us say a memory for YggR, dare!

[Who is] a protector of sanctuaries for a brother?

[Whom] does the ravager [i.e. the wolf] redden with blood?

At this point in the process of reading the text, the counterclockwise circle around the stone is completed, and the inscription meets a border which is difficult to cross: more ciphers. Some readers must have had to stop here, even if they belonged to those who knew how to read runes, and to the select few who knew all of the answers so far. Here, too, all researchers including us reach a point where interpretation becomes extremely complicated. Our proposal is just one possibility, we hope better than previous ones.

We read the narrow side (line 23) as the imperative form por of the verb pora 'to dare, be brave' (von Friesen 1920, 86), not as an invocation of Pōrr, the god Thor. The reader who is initiated into the advanced numerical cipher is challenged to say the memory for YggR, and encouraged to continue - 'to dare' - possibly also to risk mentioning the main figures in the final scenes of Ragnarok. In the following two lines (24 and 25) we accept von Friesen's solution of the numerical cross cipher (1920, 17-19). However, we propose a new lexicogrammatical reading, which takes each line as a separate clause with implicit interrogatives. On the top side of the stone (24) we do not read the name Sibbi, but the dative of $s_{i b R}$ 'brother'. Consequently, we do not find any information about Sibbi in the next line (25), but interpret the two words as Ōlni 'the ravager' and $r \bar{y} \partial_{R}$ 'redden (with blood)' (cf. Grønvik 2003, 74). ${ }^{6}$

${ }^{6} \mathrm{Grønvik}$ reconstructs an ia-stem * Ólnir whereas we posit the an-stem form. We have considered the alternative lexicogrammatical reading Ull $n \bar{e} r \bar{y} \partial_{R}$ ? (and the translation '[who] 
Both questions seem to be concerned with the same threats to the rhythm of light as have been thematised already by previous questions, namely the rivalry between the heavenly siblings and the wolf Fenrir. The answer (again) is Sól, the sun. Firstly, the sun takes the role as the protector of sanctuaries or holy places for her brother, the moon. This role rhymes with the mention of her salir 'halls' in Voluspá st. 5 and her vé 'sanctuary' in the lausavísa by Skúli Porsteinsson (Heslop 2017, 367; see above). It should be noted that the rising of the moon is also mentioned in the latter stanza: ljos ... Mána kemr ofan 'the ... light ... of Máni ... comes down'. The sun's dwellings are presumably shared with her brother the moon while taking turn resting from their heavenly travels. Secondly, we are reminded that Sól loses her life to Fenrir. Possibly rȳðr also alludes to rýðr ragna sjot 'reddens the gods' dwellings' (Voluspá st. 40) by another (or the same?) wolf, the devourer of a celestial body, in Voluspá st. 39: tungls tjúgari. There might also be a reference here to the frightful red skies of $536 \mathrm{CE}$ (and $775 \mathrm{CE}$ ). But the times of such disasters will come to an end, which will soon be clear in the concluding memory.

Finally, it should be noted that the cross cipher itself might be an iconographic clue to the answers to this pair of questions: the crosses are similar to swastikas, the symbol of the power of the sun in Iron Age iconography (see Huth and Nordberg 2005).

Last memory of the battle between the powers: the passage with questions 8-9

[cipher runes airfb $=$ sakum $][$ cipher runes $\mathbf{f r}=\mathbf{u k}][$ cipher runes bnhn $=$ mini]

[cipher runes finb $=$ uaim] [cipher runes an $=\mathbf{s i}]$ [cipher runes tfanhnu $=$ burinip]R traki uili nis pat +

[cipher runes rhfp = knua] [cipher runes rhis = knat]iatun uili nis pat +

Sagum Ygg minni,

(h) vaim sē burinn niðR, dræ̃̃ngi! Villi nē’s pat.

Knūã knätti iatun? Villi nè’s pat.

does not redden UllR with blood?'). It is a possible advantage that the grammatical subject becomes the requested element, as in the other two elliptic questions. However, we have not been able to give this reading a contextually relevant interpretation.

Futhark 9-10 (2018-2019) 
Let us say a memory for YggR,

to whom is born an offspring, to the young man! It is not a lie.

[Who] could beat a giant? It is not a lie.

In the last passage the standard interpretation identifies two references to somebody called Vilinn (lines 27 and 28). We follow instead Grønvik's $(2003,75)$ proposal that the inscription here insists twice that the preceding question asks for something that is true, not a lie (villi).

The reader is once again reminded of Odin, and challenged by two final questions. The repeated formula of confirmation ('it is not a lie') suggests that the inscription has reached a decisive point in the course of eschatological events. The memory concerns, we propose, the removal of the last threat to the light, the wolf. The answer to the first question, addressed to the dead youth Vāmoðr, is Odin, to whom Víðarr is born as an avenger, and Vídarr - the slayer of the wolf - is the answer to the second. Thus, in completing the final memory, the reader joins in the proclaiming of the victory of the gods, to which Vāmōðr will also contribute.

A condition for answering this pair of questions is that the wolf is identified as a jotunn, one of the giants, as it is indeed explicitly called in Gylfaginning (Faulkes 2005, 14) and possibly in Voluspá st. 46. Then a close parallel in Vafprúðnismál becomes evident. When Odin in the end of the poem asks about his own fate in Ragnarok, he learns from Vafprúðnir's answer that even if he will be swallowed by the wolf, he will be avenged by his son Víðarr (st. 53):

Ulfr gleypa / mun Aldafoððr, / pess mun Viððarr vreka; / kalda kjapta / hann klyfja mun / vitnis vígi at.

The wolf will devour the Father of men [i.e. Odin], this Víðarr will avenge; cold jaws of the wolf he will cleave in the moment of battle.

In the preceding stanzas ( $50 \mathrm{f}$.) the poem makes it clear that Víðarr, unlike Odin, belongs to the gods who will survive Ragnarok.

\section{Summary: the ten last runes}

[cipher runes 2:2 2:3 1:1 = nit]

(H)nit

Clash!

Futhark 9-10 (2018-2019) 
The traditional understanding of the ten last runes has been that they form a numerical cipher whose solution is nit. Given the interpretation of the inscription argued for here, a new alternative unfolds that has not been considered in previous research.

If the runes are read as a numerical cipher, the best lexical interpretation would be hnit, 'clash, battle'. ${ }^{7}$ This word is then a one-word summary for the main theme of the inscription. A similar sort of label is found on Björketorp stone (DR 360) from the seventh century, where on a separate surface it probably says "prophecy of destruction", summarizing the content of that inscription (Moltke 1985, 141). In the Eddic poem Hymiskviða (st. 23), the Midgard Serpent is called the hnitbróðir of the wolf (cf. Jónas Kristjánsson and Vésteinn Ólason 2014, 2: 403), the most likely translation of which is 'battle brother'. The battle alluded to is of course Ragnarok where all giants, in the Rök inscription represented by the wolf, will perish. This battle is also the intended destination for VāmōðR whom his father doubtlessly hoped would belong to the survivors, enjoying the bliss of the renewed Earth-and the new, now unthreatened sun-together with the remaining gods, including Víðarr.

\section{Concluding remarks}

This article offers a fundamentally novel and coherent understanding of how the Rök inscription is to be read, how it is to be translated and why it has its specific contents. Of course, we are not so arrogant as to believe that we have now solved every problem in the Rök text. Details remain to be worked out, still murky passages clarified, if possible, and many of our arguments need explaining in full. The reading order that we propose may also be questioned, but our interpretation does not depend on its absolute accuracy.

The main object for Varinn was to place the death of his son in a meaningful context of eschatological events, through a monument that would last forever. The expectations of a final battle against destructive cosmological powers - in which Varinn's son was supposed to take part - were connected to a memory of climate crisis and probably to the anxiety about a

\footnotetext{
${ }^{7}$ The word hnit itself has been identified before but used in a different interpretational framework (cf. Widmark 1992, 33 with references). The presumed lack of an initital $\mathbf{h}$ cannot be seen as an obstacle since almost all interpreters accept this for the word uaim hvaim. The representation of initial $/ \mathrm{h} /$ before a consonant varies, also in quite early Viking Age inscriptions, cf. Sm 52 Forsheda (Jansson 1984, 84) from c. 1000 CE: rhulf HrōlfR with h but lifstin Hlïfstæin without.
} 
similar one occurring. The enigmatic questions, the intricate cryptograms, and the labyrinth reading order made the monument a challenge for a select few, and a potential place for their enlightenment.

We stand on the shoulders of previous researchers and have found valuable suggestions by all of them. No longer, however, must we accept series of disassociated tales or unmotivated riddles, nor unparalleled accounts of revenge and speculations about reincarnation or proto-national conflicts. Our interpretation is firmly based on the semiotics of runestones and a close adherence to mythological Old Norse texts, and we believe that our interpretation has higher explanatory value than previous analyses. All in all, the Rök stone remains the most impressive of all runic monuments, even more stirring, we hope, with this new comprehension.

Our study shows that recent archaeological findings about the severe consequences of the climate events after $536 \mathrm{CE}$ could open for new discoveries, and it should encourage investigations into whether the eschatological motifs are present in more artifacts and runic texts than previously noted. The study definitely deepens the picture of eschatological beliefs in early Viking Age elite contexts, and the suggestion that the Rök stone monument was related to ritual speech acts in some kind of funeral context should be subject to further critical investigation. In relation to such examination, the Sitz im Leben of the monument and the ritual context of it will most likely also be further elaborated. ${ }^{8}$

\section{References}

Andrén, Anders. 2014. Tracing Old Norse Cosmology: The World Tree, Middle Earth and the Sun in Archaeological Perspectives. Roads to Midgard, 16. Stockholm.

Andersson, Thorsten. 1999. "Häjla, Rökstenens by.” In Runor och Namn: Hyllningsskrift till Lena Peterson den 27 januari 1999, ed. Lennart Elmevik and Svante Strandberg (main editors) as well as Eva Brylla, Mats Wahlberg, and Henrik Williams, 1-9. Namn och samhälle, 10. Uppsala.

Barnes, Michael P. 2007. "Rök-steinen: Noen runologiske og språklige overveielser." Maal og minne 2007: 120-32.

- 2019. The Runic Inscriptions of the Isle of Man: Based on a Manuscript by R. I. Page, and with Contributions by James E. Knirk, K. fonas Nordby, Henrik Williams, and Sir David Wilson. Runrön, 22. Uppsala and London.

\footnotetext{
${ }^{8}$ This work was partly supported by The Swedish Research Council (Rök Runestone Revisited 2016-02493). We are especially thankful for comments given by Professor Anna-Malin Karlsson, Associate professor Magnus Källström, Associate professor Andreas Nordberg, Associate professor Torun Zachrisson and our anonymous reviewers.
}

Futhark 9-10 (2018-2019) 
Bianchi, Marco. 2010. Runor som resurs: Vikingatida skriftkultur $i$ Uppland och Södermanland. Runrön, 20. Uppsala.

Brate, Erik. 1918. "Rök, kyrkogården, Lysings hd.” In Östergötlands runinskrifter, by Erik Brate, 231-55. Vol. 2 of Sveriges runinskrifter. Stockholm, 1911-18.

Browall, Hans. 2003. Det forntida Alvastra. The Museum of National Antiquities, Monographs, 6. Stockholm.

Bugge, Sophus. 1873-78. "Tolkning af runeindskriften på Rökstenen i Östergötland: Et bidrag til kundskab om svensk sprog, skrift og skaldekunst i oldtiden.” Antikvarisk tidskrift för Sverige 5: 1-148, 211-15.

— . 1910. Der Runenstein von Rök in Östergötland, Schweden. Ed. Magnus Olsen. Stockholm.

Büntgen, Ulf, Vladimir S. Myglan, Fredrik Charpentier Ljungqvist, Michael McCormick, Nicola Di Cosmo, Michael Sigl, Johann Jungclaus, Sebastian Wagner, Paul J. Krusic, Jan Esper, Jed O. Kaplan, Michiel A. C. de Vaan, Jürg Luterbacher, Lukas Wacker, Willy Tegel, and Alexander V. Kirdyanov. 2016. "Cooling and Societal Change during the Late Antique Little Ice Age from 536 to around 660 CE." Nature Geoscience 9: 231-36.

Burrows, Hannah. 2014. "Wit and Wisdom.” In Eddic, Scaldic and Beyond: Poetic Variety in Medieval Iceland and Norway, ed. Martin Chase, 114-35. Fordham Series in Medieval Studies. New York.

Charpentier Ljungqvist, Fredrik. 2010. "A New Reconstruction of Temperature Variability in the Extra-Tropical Northern Hemisphere during the Last Two Millennia.” Geografiska Annaler: Series A, Physical Geography 92: 339-51.

—. 2017. Klimatet och människan under 12000 år. Stockholm.

Clunies Ross, Margaret, ed. 2017a. "Ragnarsdrápa.” In Gade and Marold 2017, 27-46.

—. 2017b. "Pórr's fishing." In Gade and Marold 2017, 47-53.

$\mathrm{DR}+$ number $=$ inscription published in Danmarks runeindskrifter, by Lis Jacobsen and Erik Moltke, 3 vols.: Text; Atlas; Registre (København, 1941-42).

Einar Skúlason. "Fragments." See Gade 2017.

Einarsson, Bjarni, ed. 2003. Egils saga. London.

Eiríksmál. See Fulk 2012a.

Eliade, Mircea. 1987. The Sacred and the Profane: The Nature of Religion. San Diego. Espenak, Fred, and Jean Meeus. 2006. "Five Millennium Canon of Solar Eclipses." Webpage for NASA, https://eclipse.gsfc.nasa.gov/SEpubs/5MCSE.html (retrieved 2018-11-07).

Fáfnismál. In Jónas Kristjánsson and Vésteinn Ólason 2014, 2: 303-12.

Faulkes, Anthony, ed. 2005. Edda: Prologue and Gylfaginning. 2nd ed. London.

Friesen, Otto von. 1920. Rökstenen: Runstenen vid Röks kyrka, Lysings härad, Östergötland. Stockholm.

Fulk, Robert D., ed. 2012a. “Eiríksmál.” In Whaley 2012, 1003-13.

—. 2012b. "Hákonarmál." In Whaley 2012, 171-95.

Gade, Kari Ellen, ed. 2017. "[Einar Skúlason] Fragments.” In Gade and Marold 2017, 151-68. 
Gade, Kari Ellen, and Edith Marold, eds. 2017. Poetry from Treatises on Poetics. Skaldic Poetry of the Scandinavian Middle Ages, 3. Turnhout.

Gering, Hugo. 1903. Vollständiges Wörterbuch zu den Liedern der Edda. Germanistische Handbibliothek, 7.2. Halle a. S.

Grímnismál. In Jónas Kristjánsson and Vésteinn Ólason 2014, 1: 367-379.

Gräslund, Bo. 2007. "Fimbulvintern, Ragnarök och klimatkrisen år 536-537 e.Kr." Saga och sed: Kungl. Gustav Adolfs Akademiens årsbok 2007: 93-123.

Gräslund, Bo, and Neil Price. 2012. "Twilight of the Gods? 'The Dust Veil Event' of AD 536 in Critical Perspective." Antiquity 2012: 428-43.

Grønvik, Ottar. 2003. Der Rökstein: Über die religiöse Bestimmung und das weltliche Schicksal eines Helden aus der frühen Wikingerzeit. Osloer Beiträge zur Germanistik, 33. Frankfurt am Main.

Hákonarmál. See Fulk 2012b.

Halliday, Michael A. K. 1978. Language as Social Semiotic: The Social Interpretation of Language and Meaning. London.

Harris, Joseph C. 2010. "Varin's Philosophy and the Rök Stone's Mythology of Death.” In New Perspectives on Myth, ed. Wim M. J. van Binsbergen and Eric Venbrux, 91-105. Haarlem.

—. 2016. "Traditions of Eddic Scholarship." In A Handbook to Eddic Poetry: Myths and Legends of Early Scandinavia, ed. Carolyne Larrington, Judy Quinn, and Brittany Schorn, 33-57. Cambridge.

Heslop, Kate, ed. 2017. "[Skúli Porsteinsson] Lausavísa.” In Gade and Marold 2017, 366-68.

Höfler, Otto. 1952. Der Runenstein von Rök und die germanische Individualweihe. Tübingen.

Holmberg, Per. 2016. "Svaren på Rökstenens gåtor: En socialsemiotisk analys av meningsskapande och rumslighet." Futhark: International Journal of Runic Studies 6 (2015): 65-106.

Hultgård, Anders. 2017. Midgård brinner: Ragnarök i religionshistorisk belysning. Acta Academiae Regiae Gustavi Adolphi, 146. Uppsala.

Huth, Christoph, and Andreas Nordberg. 2005. "Sonnensymbol." In Reallexikon der Germanischen Altertumskunde, founded by Johannes Hoops, ed. Heinrich Beck, Dieter Geuenich, and Heiko Steuer, 29: 239-44. 2nd ed. Berlin and New York.

Hymiskviða. In Jónas Kristjánsson and Vésteinn Ólason 2014, 1: 399-407.

Jacobsen, Lis. 1961. "Rökstudier." Arkiv för nordisk filologi 76: 1-50.

Jansson, Sven B. F. 1987. Runes in Sweden. Stockholm.

Jónas Kristjánsson and Vésteinn Ólason, eds. 2014. Eddukvæði. 2 vols. Íslenzk fornrit. Reykjavík.

Jónsson, Finnur, ed. 1912. Den norsk-islandske skjaldedigtning. B. Rettet tekst, vol. 1. København and Kristiania.

Källström, Magnus. 2016. "Bär den norska Vangstenen ett Ragnaröksmotiv?" Fornvännen 111: 268-71. 
Lincoln, Bruce. 1986. Myth, Cosmos, and Society: Indo-European Themes of Creation and Destruction. Cambridge, Mass., and London.

Lindroth, Hjalmar. 1911. "Bidrag till Rökstensinskriftens tolkning.” Studier i nordisk filologi 2.8: 1-16.

Lönnqvist, Olov. 1999. "Vilken väg valde Varin? Läsvägar på Rökstenen.” Saga och sed: Kungl. Gustav Adolfs Akademiens årsbok 1999: 117-36.

Lönnroth, Lars. 1977. "The Riddles of the Rök-stone: A Structural Approach." Arkiv för nordisk filologi 92: 1-57.

Löwenborg, Daniel. 2012. "An Iron Age Shock Doctrine: Did the AD 536-7 Event Trigger Large-Scale Social Changes in the Mälaren Valley Area?" Journal of Archaeology and Ancient History 4: 3-29.

Malone, Kemp. 1934. "The Theodoric of the Rök inscription." Acta philologica Scandinavica 9: 76-84

Meulengracht Sørensen, Preben. 1991. “Om eddadigtenes alder.” In Nordisk hedendom: Et symposium. Ed. Gro Steinsland, Ulf Drobin, Juha Pentikäinen, and Preben Meulengracht Sørensen, 217-28. Odense.

Moltke, Erik. 1985. Runes and their Origin, Denmark and Elsewhere. Copenhagen.

$\mathrm{N}+$ no. = inscription published in Norges innskrifter med de yngre runer, by Magnus Olsen et al., 6 vols. to date (Oslo, 1941-).

Naumann, Hans-Peter, in collaboration with Marco Bianchi and Ulrike MarxAlberding. 2018. Metrische Runeninschriften in Skandinavien: Einführung, Edition und Kommentare. Tübingen.

Nielsen, Niels Åge. 1969. Runerne på Rökstenen. Odense University Studies in Scandinavian Linguistics, 2. Odense.

Nordberg, Andreas. 2003. Krigarna i Odins sal: Dödsföreställningar och krigarkult. Stockholm.

Nordenstreng, Rolf. 1912. "Vad är syftet med Rökstenens inskrift." Studier $i$ nordisk filologi 3: 1-4.

Nordin, Fredrik S. 1903. "Till frågan om de gotländska bildstenarnas utvecklingsformer.” Studier tillägnade Oscar Montelius 9/3 1903 af lärjungar, 142-55. Stockholm.

Nylén, Erik. 1988. Stones, Ships and Symbols: The Picture Stones of Gotland from the Viking Age and Before. Stockholm.

Olsen, Magnus. 1921. "Til Rök-indskriften." Arkiv för nordisk filologi 37: 201-32.

Peterson, Lena. 2006. Svenskt runordsregister. 3. uppl. Runrön, 2. Only available online: http://urn.kb.se/resolve?urn=urn:nbn:se:uu:diva-157958

Pipping, Hugo. 1932. "Rökstensinskriften en rättsurkund." Studier i nordisk filologi 22.1: 50-2.

Price, Neil. 2010. "Passing into Poetry: Viking-Age Mortuary Drama and the Origins of Norse Mythology.” Medieval Archaeology 54: 123-55.

Price, Neil, and Bo Gräslund. 2015. "Excavating the Fimbulwinter? Archaeology, Geomythology and the Climate Event(s) of AD 536." In Past Vulnerability: Volcanic Eruptions and Human Vulnerability in Traditional Societies Past and Present, ed. Felix Riede, 109-32. Aarhus. 
Ragnarsdrápa. See Clunies Ross 2017a.

Ralph, Bo. 2007. "Gåtan som lösning: Ett bidrag till förståelsen av Rökstenens runinskrift.” Maal og minne 2007: 133-57.

Schjødt, Jens Peter. 2008. Initiation between Two Worlds: Structure and Symbolism in Pre-Christian Scandinavian Religion. The Viking Collection, 17. Odense.

Schück, Henrik. 1908. Bidrag till tolkning af Rök-inskriften. Uppsala.

Seip, Didrik Arup. 1931. "Pronomenet hvem i gammelnorsk." In his Studier i norsk språkhistorie, 32-35. Oslo.

Sigl, M., M. Winstrup, J. R. McConnell, K. C. Welten, G. Plunkett, F. Ludlow, U. Büntgen, M. Caffee, N. Chellman, D. Dahl-Jensen, H. Fischer, S. Kipfstuhl, C. Kostick, O. J. Maselli, F. Mekhaldi, R. Mulvaney, R. Muscheler, D. R. Pasteris, J. R. Pilcher, M. Salzer, S. Schüpbach, J. P. Steffensen, B. M. Vinther, and T. E. Woodruff. 2015. "Timing and Climate Forcing of Volcanic Eruptions for the Past 2,500 Years." Nature 523: 543-49.

Skúli Porsteinsson. "Lausavísa." See Heslop 2017.

Sonatorrek. In Einarsson 2003, 146-54.

Ström, Fredrik. 1939. Svenska folkgåtor. Stockholm.

Sukhodolov, Timofei, Ilya Usoskin, Eugene Rozanov, et al. 2017. "Atmospheric Impacts of the Strongest Known Solar Particle Storm of 775 AD.” Scientific Reports 7, 45257. https://doi.org/10.1038/srep45257

Sundqvist, Olof. 2002. Freyr's Offspring: Rulers and Religion in Ancient Svea Society. Acta Universitatis Upsaliensis, Historia Religionum, 21. Uppsala.

— . 2010. "Om hängningen, de nio nätterna och den dyrköpta kunskapen i Hávamál 138-45: Den kultiska kontexten.” Scripta Islandica 2010: 68-96.

—. 2016. An Arena for Higher Powers: Ceremonial Buildings and Religious Strategies for Rulership in Late Iron Age Scandinavia. Leiden and Boston.

Sö + no. $=$ inscription published in Södermanlands runinskrifter, by Erik Brate and Elias Wessén = Sveriges runinskrifter, vol. 3 (Stockholm, 1924-36).

Thorvaldsen, Bernt Ø. 2016. "The Dating of Eddic Poetry.” In A Handbook to Eddic Poetry: Myths and Legends of Early Scandinavia, ed. Carolyne Larrington, Judy Quinn, and Brittany Schorn, 72-91. Cambridge.

Toohey, Matthew, Kirstin Krüger, Michael Sigl, Frode Stordal, and Henrik Svensen. 2016. "Climatic and Societal Impacts of a Volcanic Double Event at the Dawn of the Middle Ages." Climatic Change 136: 401-12.

Vafpruðnismál. In Jónas Kristjánsson and Vésteinn Ólason 2014, 1: 356-66.

Wessén, Elias. 1958. Runstenen vid Röks kyrka. Kungl. Vitterhets Historie och Antikvitets Akademien, Handlingar, filologisk-filosofiska ser., 5. Stockholm.

Whaley, Diana, ed. 2012. Poetry from the Kings' Sagas, vol. 1. Skaldic Poetry of the Scandinavian Middle Ages, 1. Turnhout.

Widgren, Mats. 1983. Settlement and Farming Systems in the Early Iron Age: A Study of Fossil Agrarian Landscapes in Östergötland, Sweden. Acta Universitatis Stockholmiensis, Stockholm Studies in Human Geography. Stockholm.

— . 2013. "Climate and Causation in the Swedish Iron Age: Learning from the Present to Understand the Past." Geografisk tidsskrift 112.2: 126-34. 
Widmark, Gun. 1992. "Varför ristade Varin runor? Tankar kring Rökstenen." Saga och sed: Kungl. Gustav Adolfs Akademiens årsbok 1992: 25-44.

Vigfússon, Guðbrandur, and Frederick York Powell. 1879. An Icelandic Prose Reader, with Notes, Grammar, and Glossary. Oxford.

Williams, Henrik. 2013. "Runstenarnas sociala dimension." Futhark: International Journal of Runic Studies 4: 61-76.

Williamson, Craig, ed. 1977. The Old English Riddles of the Exeter Book. Chapel Hill.

Voluspá. In Jónas Kristjánsson and Vésteinn Ólason 2014, 1: 292-321.

Åkerström, Hanna. 2019. "Det tidigvikingatida runmaterialet: En inventering." Futhark: International fournal of Runic Studies 8 (2017): 7-88.

Òg + no. $=$ inscription published in Östergötlands runinskrifter, by Erik Brate $=$ Sveriges runinskrifter, vol. 2 (Stockholm, 1911-18). 